\title{
29. MULTISPECIES PLANKTONIC FORAMINIFER STABLE ISOTOPE STRATIGRAPHY THROUGH OLIGOCENE/MIOCENE BOUNDARY CLIMATIC CYCLES, SITE $926^{1}$
}

\author{
Paul N. Pearson, ${ }^{2}$ Nicholas J. Shackleton, ${ }^{3}$ Graham P. Weedon, ${ }^{4}$ and Mike A. Hall ${ }^{3}$
}

\begin{abstract}
The oxygen and carbon isotopic ratios of 12 multispecimen samples of different extinct species of planktonic foraminifer are assessed to establish their relative depth ranking in a sample from near the Oligocene/Miocene boundary. Of these, the following species (with their interpreted depth habitats) were selected for high-resolution isotope stratigraphy: Catapsydrax dissimilis (subthermocline intermediate water), Globoquadrina venezuelana (lower thermocline), Paragloborotalia mayeri (upper thermocline), Paragloborotalia pseudokugleri (mixed layer), and Globigerina praebulloides (mixed layer). Two cyclic stratigraphic intervals are selected within Core 154-926B-50X, which straddles the Oligocene/Miocene boundary. Very little consistent variation is seen in $\delta^{18} \mathrm{O}$ of the mixed-layer and upper thermocline species through the pronounced light-dark obliquitydriven lithologic cycles in the core. This indicates that the environmental variation that caused the lithologic cycles occurred in the absence of marked sea-surface temperature change, and also without significant ice-volume fluctuations. A slight but significant positive deflection is seen in the records of the deep and lower thermocline species in some of the dark bands. It is therefore hypothesized that periodic high-latitude cooling caused the influx of relatively cold bottom waters on the Ceara Rise, enhancing local dissolution and sometimes affecting subthermocline temperatures, but not affecting the upper part of the water column. There is no regular variation in the inter-species $\delta^{13} \mathrm{C}$ gradient. However, parallel cyclic variations in the $\delta^{13} \mathrm{C}$ of all species are observed, possibly with a slight phase lag with respect to the lithologic cycles and some higher frequency variation. These results point to cyclic changes in the global carbon balance during the Oligocene-Miocene transition interval.
\end{abstract}

\section{INTRODUCTION}

Much of the Cenozoic sedimentary record on the Ceara Rise is characterized by light-dark lithologic cycles of decimeter and meter thicknesses. These changes in light reflectance indicate variation in the relative concentration of pelagic carbonate and terrestrial clay. Reflectance variation is in-phase with other measurements that respond to clay content, such as natural gamma-ray emission and magnetic susceptibility. This study focuses on pronounced lithologic cycles in the upper Oligocene through lower Miocene in Hole 926B. Spectral analysis of the magnetic susceptibility record in this interval and for most of the Oligocene indicates that the banding is very regular and the dominant cyclic frequency is about $1 \mathrm{~m}$ (Weedon et al., this volume). This regularity is interpreted as a response to a strong climatic forcing of lithology by secular changes in the Earth's axial obliquity (Weedon et al., this volume).

Oligocene and lower Miocene sections that show Milankovitchscale climatic variation are relatively rare (see Mead et al., 1986; Van Echelpoel and Weedon, 1990; Hartl et al., 1995). Clearly, the sedimentary system on the Ceara Rise was unusually sensitive to climatic change at that time. This paper aims to investigate the nature of this ancient climatic variability. We present high-resolution carbon $\left(\delta^{13} \mathrm{C}\right)$ and oxygen $\left(\delta^{18} \mathrm{O}\right)$ stable isotopic records from multiple species of planktonic foraminifer through several lithologic cycles in Core 154926B-50X, in which the Oligocene/Miocene boundary is recognized by micropaleontological criteria (see below). The objective is to estimate at which preferred depth the various species of foraminifer cal-

${ }^{1}$ Shackleton, N.J., Curry, W.B., Richter, C., and Bralower, T.J. (Eds.), 1997. Proc. $O D P$, Sci. Results, 154: College Station, TX (Ocean Drilling Program).

${ }^{2}$ Department of Geology, University of Bristol, Wills Memorial Building, Queen's Road, Bristol BS8 1RJ, United Kingdom. paul.pearson@bris.ac.uk

${ }^{3}$ Gowdin Laboratory, Department of Earth Sciences, University of Cambridge, Free School Lane, Cambridge CB2 3RS, United Kingdom.

${ }^{4}$ School of Geological Science, University of Luton, Park Square, Luton, Bedfordshire LU1 3JU, United Kingdom. cified and use them to monitor changing conditions during different phases of each climatic cycle.

The advantage of using multiple species is that mixed layer, thermocline, and deep-water variations can be independently monitored and deconvolved from total water column variability. Although we do not know what series of causal links connect orbital variations to Oligocene-Miocene lithologic cycles on the Ceara Rise, it is likely that changes in the chemical conditions in the water column were involved. If these changes were accompanied by variations in the local sea-surface temperature or the vertical thermal gradient, we would expect to see a signal in the $\delta^{18} \mathrm{O}$ of at least some species. If significant changes in the local biological productivity or carbonate chemistry were involved, a signal in the $\delta^{13} \mathrm{C}$ of certain species would occur. If there was an alternation between different surface- or deepwater masses in the area, both the $\delta^{18} \mathrm{O}$ and the $\delta^{13} \mathrm{C}$ from foraminifers in different parts of the water column might change. Total water column variations reflecting, for example, global ice volume changes (affecting $\delta^{18} \mathrm{O}$ ) or organic carbon reservoirs (affecting $\delta^{13} \mathrm{C}$ ) would be likely to be visible in the records of all species.

\section{METHODS}

We have sampled Oligocene/Miocene boundary climatic cycles at Site 926 because it is the shallowest site in which the interval was recovered, and hence is likely to have the best-preserved foraminifers. Also, by virtue of it being less dissolved than the deeper Sites 928 and 929, it has a higher sedimentation rate (Curry, Shackleton, Richter, et al., 1995). Two important datums that lie close to the generally accepted Oligocene/Miocene boundary level are found within Core 154-926B-50X. The first is the top of the nannofossil Sphenolithus delphix between Samples 154-926B-50X-6, $80 \mathrm{~cm}$, and 50X-6, 110 cm (499.51 and 499.81 meters composite depth [mcd]; Curry, Shackleton, Richter, et al., 1995), which we use provisionally to identify the boundary. The second is the base of the planktonic foraminifer Paragloborotalia kugleri between Samples 154-926B-50X-3, 70-72 cm, and 50X-4, 70-72 cm (494.92 and 496.42 mcd; Pearson and Chais- 
son, this volume). The Paleogene/Neogene working group of the International Commission on Stratigraphy recommended defining the boundary at the level of this datum in the Rigorosa Formation of northwest Italy (Steininger, 1994; see also Berggren et al., 1995). Unfortunately, in this study it was found that the datum is difficult to determine precisely at Milankovitch-scale resolution because it is a gradual transition. Of course, if it turns out that some other datum level best approximates the boundary, the study interval may eventually be found to be wholly within the lowermost Miocene or the uppermost Oligocene.

Full sediment recovery $(9.6 \mathrm{~m})$ was achieved in Core 154-926B$50 \mathrm{X}$. Eight complete lithologic cycles are visible in the core photograph (Fig. 1). They are similar, but not identical, in character and display some evidence for shorter wavelength reflectance changes. The lithology alternates between pale yellowish green nannofossil chalk with clay and greenish gray clayey nannofossil chalk. The sediment is moderately bioturbated throughout and color contacts are gradational (for further details, see Shipboard Scientific Party, 1995).

Sediment samples of $10 \mathrm{~cm}^{3}$ were taken at $10-\mathrm{cm}$ intervals (approximating a temporal spacing between samples of $4000 \mathrm{yr}$, assuming the cycles are obliquity cycles). Care was taken to avoid minor fractures caused by the drilling process. Two intervals, near the top and bottom of the core respectively, were selected for isotopic analysis. This strategy allows us to analyze several cycles and also determine whether there is any change in their isotopic characteristics from the bottom to the top of the core. The sampling intervals are 1) between Sample 154-926B-50X-1, 14-16 cm, and 50X-3, 44-46 cm (461.54 to 464.84 meters below seafloor [mbsf]; 491.35 to 494.65 mcd), and 2) between Samples 154-926B-50X-5, 4-6 cm, and 50X$6,77-76 \mathrm{~cm}$ (467.44 to $469.67 \mathrm{mbsf} ; 497.25$ to $499.48 \mathrm{mcd}$ ).

Samples were washed over a $63-\mu \mathrm{m}$ sieve and oven dried. Stable isotopic measurements were made on multiple planktonic foraminifer specimens of typical adult size. We did not control the size fraction from which specimens were picked because subtle ecophenotypic size changes might have occurred in response to environmental factors, in which case that method would be likely to screen out some of the environmental information we are interested in. Nevertheless, systematic size variations were not observed in any species. The number of individuals picked for each isotopic sample varied, depending on the number available and the typical size of the species. The mean number of foraminifers picked for each measurement is as follows: Catapsydrax dissimilis, 15; Globigerina praebulloides, 32; Globoquadrina venezuelana, 19; Paragloborotalia mayeri, 45; and Paragloborotalia pseudokugleri, 85. Samples were crushed and acetone was added to enable the removal of fine particulates such as nannofossils by capillary action using tissue paper. Samples were then treated with hydrogen peroxide to oxidize any remaining organic contaminants. Measurements were made using a VG Prism mass spectrometer at the Godwin Laboratory, University of Cambridge, and isotopic values are expressed in standard notation relative to the Peedee belemnite standard.

\section{PRESERVATION}

Selected samples were studied by scanning electron microscope to assess their state of preservation (e.g., Pearson and Chaisson, this volume, Plate 2, Figs. 12,16). As is usual in paleontological samples, all specimens are "recrystallized" to the extent that they do not show the internal submicron granular texture that is characteristic of pristine foraminifer tests. However, despite the relatively great burial depth (between 460 and $470 \mathrm{mbsf}$ ), there is very little evidence of more severe recrystallization such as growth of inorganic calcite crystals on the outside or inside walls of the tests. Evidence from a neighboring site (Site 925) on the Ceara Rise indicates that there is a sharp diagenetic transition from chalk to limestone at $\sim 700 \mathrm{mbsf}$

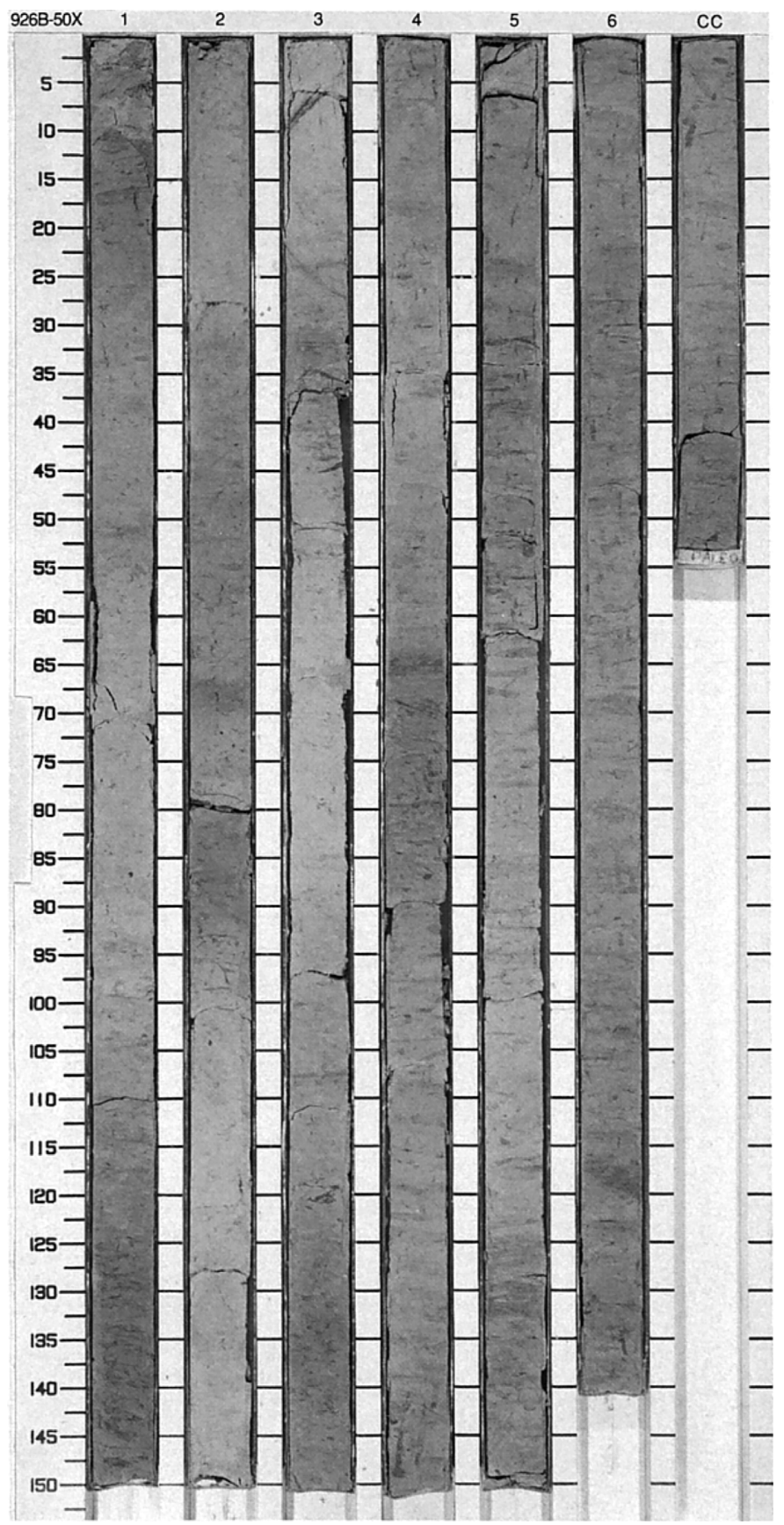

Figure 1. Photograph of Core 154-926B-50X. Note the alternation between light and dark bands.

(Curry, Shackleton, Richter, et al., 1995). Above this level, significant overgrowths of calcite are rarely seen. Those few specimens that did show small calcite overgrowths were not picked.

Another potential difficulty for isotopic analysis is dissolution. All samples show some evidence for dissolution, such as the presence of corroded and fragmentary specimens. Samples from the darker lithologic bands are more intensively dissolved and often dominated by fragments. Dissolution-resistant forms such as Catapsydrax dissimilis and benthic foraminifers are concentrated in these samples, whereas dissolution-susceptible forms such as Globigerina praebulloides are rare. Dissolution could conceivably affect the isotopic ra- 
tios of a species by removing the more soluble calcite from the test, which might be isotopically distinct from the test as a whole. However, the consistency of the results we obtained through the pronounced lithologic cycles (see below), particularly in $\delta^{18} \mathrm{O}$ which is generally more susceptible to diagenetic effects than $\delta^{13} \mathrm{C}$, suggests that the varying degrees of dissolution and recrystallization had virtually no effect on the isotopic ratios obtained.

\section{FORAMINIFER DEPTH HABITATS}

Although most species of planktonic foraminifer migrate through the water column during their life cycle, the bulk of test calcite (that is, the last one or two chambers and a gametogenic crust, if present) tends to be secreted within a restricted depth range (Hemleben et al., 1989). The preferred depth of calcification varies from species to species. Broadly speaking, modern and ancient open ocean faunas can be divided into mixed layer, thermocline, and subthermocline calcifiers. Differences in the environment of calcification, and to some extent the physiology of the organisms, accounts for the significant range of geochemical and isotopic composition of sedimented shells that is usually observed between species from any same sediment sample.

Because all the species of interest are extinct, we must rely on isotopic and geochemical techniques for establishing their preferred depth of calcification. Both carbon and oxygen isotopes can be used to infer depth habitat information (see Pearson et al., 1993, for a fuller discussion). The oxygen isotopic ratio of test calcite reflects mainly the isotopic composition of seawater, the temperature of calcification, the local salinity and potentially small species-specific vitaleffect fractionation. In general, for comparisons among shells from a single sediment sample, the most negative $\delta^{18} \mathrm{O}$ values suggest the warmest calcification conditions (Emiliani, 1954). Carbon isotopes reflect mainly the isotopic composition of dissolved $\mathrm{CO}_{2}$ in the water from which the foraminifer calcifies. Surface waters tend to contain dissolved $\mathrm{CO}_{2}$, which has higher $\delta^{13} \mathrm{C}$ ratios than deeper waters because of the so-called "biological pumping" effect: photosynthesis in the euphotic zone preferentially fixes the light isotope of carbon into organic particles that, after sinking, oxidize at depth (Kroopnick, $1985)$. In addition to this effect, species with symbionts tend to calcify in a microenvironment with higher $\delta^{13} \mathrm{C}$ values than the immediate surrounding water because of their symbiont photosynthesis (Spero and Williams 1988, 1989; Spero, 1992; Bijma et al., 1995). It is also probable that other less well understood vital effects exist, including for some species mechanisms by which the shell has isotopically lower $\delta^{13} \mathrm{C}$ values than the surrounding water (Erez and Honjo, 1981; Pearson and Shackleton, 1995).

To obtain the maximum habitat information from a fauna, carbon and oxygen isotopes are best considered simultaneously. This is because the rapid temperature change with depth that defines the thermocline does not necessarily correspond to a rapid change in $\delta^{13} \mathrm{C}$; therefore, an inflection is commonly observed when the $\delta^{18} \mathrm{O}$ of a fauna is plotted against its $\delta^{13} \mathrm{C}$. As discussed by Spero and Williams (1989) and Pearson et al. (1993), the expected shape of a plot in which $\delta^{18} \mathrm{O}$ (with axis reversed, as is conventional) is plotted against $\delta^{13} \mathrm{C}$ is a "J"-shape, at least for sites with a year-round stable thermocline. The toe of the "J" includes species with relatively high $\delta^{18} \mathrm{O}$ values, indicating cold water, and low $\delta^{13} \mathrm{C}$ values, indicating local oxidation of organic matter. These are the conditions that prevail below the thermocline. Species that are distributed through the thermocline are expected to plot nearer the inflection of the curve and exhibit a range of $\delta^{18} \mathrm{O}$ values, but relatively constant $\delta^{13} \mathrm{C}$ values. Species that calcify in the mixed layer tend to have the most negative $\delta^{18} \mathrm{O}$ because they are in the warmest water, but typically exhibit a range of $\delta^{13} \mathrm{C}$ values caused by either depth stratification as picked out by the local gradient of $\delta^{13} \mathrm{C}$ in dissolved $\mathrm{CO}_{2}$, or by the presence in some species of active symbionts, which makes them appear anomalously positive with respect to $\delta^{13} \mathrm{C}$. Thus, although it is not possible to reconstruct the absolute depth of the thermocline from a sediment sample, the influence of the thermocline on the isotopes can be identified and the relative depth habitats of species can be estimated by their position with respect to it. It should always be kept in mind, however, that vital effect fractionation in some species may give anomalous or misleading results.

Figure 2 shows a $\delta^{18} \mathrm{O}$ vs. $\delta^{13} \mathrm{C}$ plot of 12 multispecimen samples of different species of planktonic foraminifer from a single sediment sample (Sample 154-926B-50X-5, 4-6 cm). The data are given in Table 1 . The species distribute isotopically in a similar way to a modern low-latitude fauna, suggesting a comparable range of depth habitats and ecologies.

Catapsydrax dissimilis is the most positive with respect to $\delta^{18} \mathrm{O}$ and most negative with respect to $\delta^{13} \mathrm{C}$ and so is interpreted as a relatively deep-water calcifier. A similar interpretation for Catapsydrax spp. was made by Douglas and Savin (1978), Poore and Matthews (1984), Boersma et al. (1987), Keller (1985), and Corfield and Cartlidge (1991).

Globoquadrina venezuelana and the very similar form Globoquadrina euaperta give almost identical isotopic values indicative of deeper thermocline depths. The two differ mainly by the larger and more encrusted shells of individuals assigned to $G$. venezuelana, and

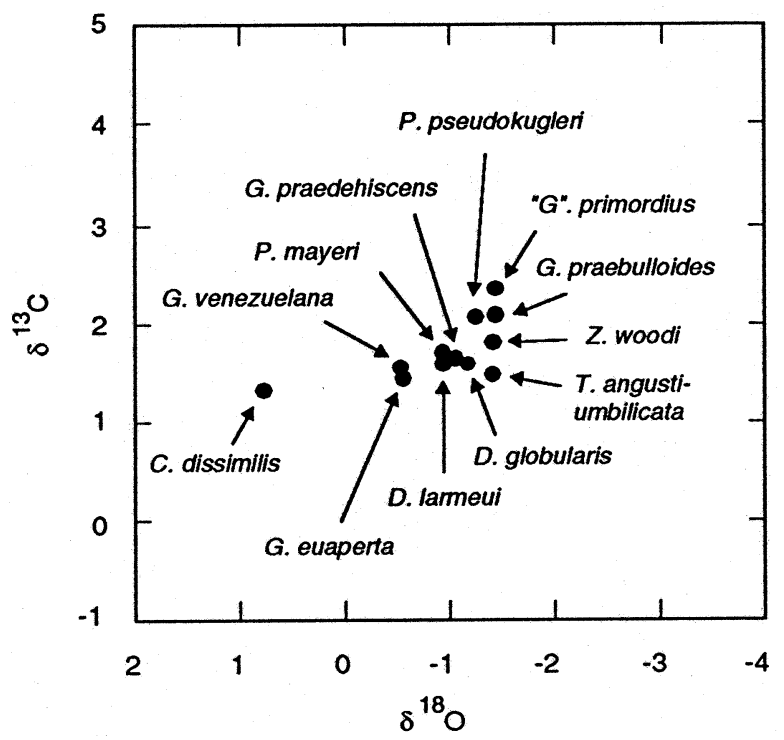

Figure 2. Stable isotopic ratios given by twelve multispecimen samples of different extinct species of planktonic foraminifer from Sample 154-926B$50 \mathrm{X}-5,4-6 \mathrm{~cm}$. See text for discussion.

Table 1. Planktonic foraminifer stable isotope data for Sample 154926B-50X-5, 4-6 cm.

\begin{tabular}{|c|c|c|c|}
\hline Species & $\begin{array}{c}\text { No. } \\
\text { specimens }\end{array}$ & $\begin{array}{l}\delta^{18} \mathrm{O} \\
(\% o)\end{array}$ & $\begin{array}{l}\delta^{13} \mathrm{C} \\
(\% \circ)\end{array}$ \\
\hline Catapsydrax dissimilis & 16 & 0.76 & 1.27 \\
\hline Dentoglobigerina globularis & 25 & -1.20 & 1.52 \\
\hline Dentoglobigerina larmeui & 28 & -0.97 & 1.53 \\
\hline Globigerina praebulloides & 82 & -1.46 & 2.03 \\
\hline "Globigerinoides" primordius & 23 & -1.47 & 2.31 \\
\hline Globoquadrina euaperta & 31 & -0.58 & 1.40 \\
\hline Globoquadrina praedehiscens & 38 & -1.08 & 1.59 \\
\hline Globoquadrina venezuelana & 23 & -0.56 & 1.50 \\
\hline Paragloborotalia mayeri & 31 & -0.96 & 1.66 \\
\hline Paragloborotalia pseudokugleri & 51 & -1.26 & 2.02 \\
\hline Tenuitellinata angustiumbilicata & 135 & -1.43 & 1.44 \\
\hline Zeaglobigerina woodi & 58 & -1.43 & 1.76 \\
\hline
\end{tabular}


the more coarsely cancellate wall of $G$. euaperta, but they may be morphotypes within the same biological species. Although Poore and Matthews (1984) recorded a relatively warm paleotemperature for $G$. venezuelana, it has elsewhere been interpreted as a monitor of colder "deep" water conditions (e.g., Barrera et al., 1985; Keller, 1985; Gasperi and Kennett, 1992, 1993; Hodell and Vayavananda, 1994; Norris et al., 1993; Corfield and Cartlidge, 1993; Pearson and Shackleton, 1995). It is noteworthy that a large negative $\delta^{18} \mathrm{O}$ offset is observed between this species and Catapsydrax dissimilis in this material, indicating that it is not necessarily the deepest dweller in a fauna.

Species that appear to have calcified in the higher thermocline region are Dentoglobigerina larmeui, Dentoglobigerina globularis, Paragloborotalia mayeri, and Globoquadrina praedehiscens. To our knowledge, no isotopic data has previously been gathered for $D$. larmeui. D. globularis was found to be among the relatively warmwater calcifiers by Poore and Matthews (1984). P. mayeri has also been interpreted as a shallow-water dweller (Keller 1985; Gasperi and Kennett, 1992), although the latter authors noted that $P$. mayeri is relatively depleted in $\delta^{13} \mathrm{C}$ as well as $\delta^{18} \mathrm{O}$, which is indicative of the upper thermocline. Pearson and Shackleton (1995) showed that in the middle Miocene, $P$. mayeri had upper thermocline values similar to the Fohsella lineage. G. praedehiscens has not previously been examined isotopically, but the descendent form, Globoquadrina dehiscens, has been interpreted variously as an upper-intermediate dweller (Keller 1985), a deep dweller (Corfield and Cartlidge, 1991; Gasperi and Kennett, 1992) or isotopically erratic (Pearson and Shackleton, 1995).

Mixed-layer dwellers include Tenuitellinata angustiumbilicata, Zeaglobigerina woodi, Paragloborotalia pseudokugleri, Globigerina praebulloides, and "Globigerinoides" primordius. Curiously, both G. praebulloides and Z. woodi were recorded as relatively deep dwellers by Keller (1985) from mid-latitude material. However, the descendants of these forms are almost exclusively shallow-water dwellers. None of the others have previously been analyzed, but Paragloborotalia kugleri, a lineal descendant of P. pseudokugleri, was recorded as a surface dweller by Keller (1985).

Five of these species were selected for conducting isotope stratigraphy to obtain a full habitat range for the fauna. These are Catapsydrax dissimilis (sub-thermocline intermediate water), Globoquadrina venezuelana (deeper thermocline), Paragloborotalia mayeri (shallower thermocline), Globigerina praebulloides (mixed layer) and Paragloborotalia pseudokugleri - kugleri (mixed layer). Only the latter species pair, which represents a single lineage, underwent considerable evolutionary change in the time interval of study.

\section{RESULTS}

Table 2 shows the stratigraphic oxygen and carbon isotopic data for the five selected planktonic foraminifer species. Figure 3 shows oxygen and carbon isotope stratigraphies for the five selected planktonic foraminifer species in the higher part of Core 154-926B-50X alongside the $550 \mathrm{~nm}$ light reflectance curve (in percent) for that interval (Curry, Shackleton, Richter, et al., 1995). A similar plot for the lower sampling interval is given in Figure 4. In these figures, boundaries of the lithologic cycles have been delineated by dotted vertical lines using minima in the reflectance curve. If the lithologic cycles are indeed obliquity cycles as argued by Weedon et al. (this volume), then each cycle represents about 40,000 yr at this time in Earth history (Berger and Loutre, 1994). Note that the upper stratigraphic interval encompasses three whole lithologic cycles and the lower interval encompasses nearly two cycles.

The first point of interest is that although the relative isotopic positions of the different species are broadly maintained through the core, some subtle interspecies crossovers occur. For example, Globigerina praebulloides is generally a little more negative with respect to $\delta^{18} \mathrm{O}$ than Paragloborotalia kugleri in most of the top sampling interval (Fig. 3), but in the bottom interval the reverse is true (Fig. 4). Paragloborotalia mayeri is consistently more positive than Globoquadrina venezuelana in $\delta^{13} \mathrm{C}$ near the top of the core (Fig. 3), but the two are almost indistinguishable in the lower sampling interval (Fig. 4). The fact that these changes occur over long periods with respect to the Milankovitch cycles suggests that they are not driven by environmental changes, and so are probably subtle evolutionary effects relating to either habitat or metabolism.

Throughout the sample intervals, the $\delta^{18} \mathrm{O}$ of the most negative of the mixed-layer dwellers lies mostly in a very narrow range between $-1.6 \%$ and $-1.9 \%$. On the time scale of the lithologic cycles there is little consistent variation in $\delta^{18} \mathrm{O}$ of the shallower species. The deeper water dwellers Catapsydrax dissimilis and Globoquadrina venezuelana exhibit some covariation in $\delta^{18} \mathrm{O}$, particularly in the upper time interval. Similarly to the $\delta^{18} \mathrm{O}$ records, there is little change in the long-term $\delta^{13} \mathrm{C}$ values given by the different species from bottom to top in the core, except that the deeper water dwellers tend to have marginally more negative $\delta^{13} \mathrm{C}$ than in the higher interval (Fig. 3). Unlike the oxygen records, Milankovitch-scale variations in $\delta^{13} \mathrm{C}$ are more prominent. Although the data are limited, each lithologic cycle appears to contain one long cycle in $\delta^{13} \mathrm{C}$ and some higher frequency variations. Minima in reflectance approximate to minima in $\delta^{13} \mathrm{C}$, possibly with a slight phase shift whereby $\delta^{13} \mathrm{C}$ minima occur a little higher in the core than reflectance minima. The cycle centered on 498 $\mathrm{m}$ appears to contain approximately two cycles in $\delta^{13} \mathrm{C}$, which are visible to a comparable extent in all species. In all, the data indicate total water-column variations in $\delta^{13} \mathrm{C}$ of about $\pm 0.5 \%$. There is no close relationship between variations in $\delta^{13} \mathrm{C}$ and the slight variations in $\delta^{18} \mathrm{O}$ that were observed in the records of Globoquadrina venezuela$n a$ and Catapsydrax dissimilis.

\section{DISCUSSION AND CONCLUSION}

The lack of obvious cyclicity in the $\delta^{18} \mathrm{O}$ values of the shallowdwelling planktonic foraminifers Globigerina praebulloides and Paragloborotalia pseudokugleri/kugleri is an unexpected result and requires detailed consideration. Several factors might have been expected to have caused cyclic variation in $\delta^{18} \mathrm{O}$ with the same wavelength as the color bands. These include global ice-volume changes, which would have an inevitable effect on the mean $\delta^{18} \mathrm{O}$ of seawater, surface water temperature changes at the Ceara Rise, and variations in the effects of diagenesis (e.g., enhanced dissolution in the darker bands might have preferentially removed the more soluble calcite from foraminifer tests, potentially altering the measured $\delta^{18} \mathrm{O}$ ). It is possible that such changes have acted in such a way as to cancel each other out. However, such a scenario is considered unlikely given 1) the degree of consistency observed in the $\delta^{18} \mathrm{O}$ records, and 2) the fact that some long-term changes in the relative $\delta^{18} \mathrm{O}$ of the two species are observed, but not on the scale of individual cycles. An unstable balance between multiple causes is unlikely to have produced such a result. Preferring the simplest explanation, the $\delta^{18} \mathrm{O}$ values given by the shallow-dwelling species suggests that the sea-surface temperature was constant to within $1^{\circ}-2^{\circ} \mathrm{C}$ and the isotopic ratio of seawater was also fairly constant. If this interpretation is correct, the slight variation in the $\delta^{18} \mathrm{O}$ of the deeper dwelling forms Catapsydrax dissimilis and Globoquadrina venezuelana indicates subtle deep and subthermocline cooling events at about $492.5 \mathrm{mcd}, 494.5 \mathrm{mcd}$, and 497.5 mcd associated with the reflectance minima. No such cooling was associated with the reflectance minima at about $491.3 \mathrm{mcd}$ and $493.5 \mathrm{mcd}$.

Flower et al. (Chapter 28, this volume), observed Milankovitchscale cyclicity in benthic foraminifer $\delta^{18} \mathrm{O}$ from the correlative level in Site 929 . The results given here indicate that although the cyclicity seen by Flower et al. (this volume) may correlate with some of the 
Table 2. Planktonic foraminifer stratigraphic stable isotope data from Core 154-926B-50X.

\begin{tabular}{|c|c|c|c|c|c|c|c|}
\hline $\begin{array}{c}\text { Section, } \\
\text { interval }(\mathrm{cm})\end{array}$ & $\begin{array}{l}\text { Depth } \\
\text { (mcd) }\end{array}$ & $\begin{array}{c}\text { No. } \\
\text { specimens }\end{array}$ & $\begin{array}{l}\delta^{18} \mathrm{O} \\
(\% \circ)\end{array}$ & $\begin{array}{l}\delta^{13} \mathrm{C} \\
(\% o)\end{array}$ & $\begin{array}{c}\text { Section, } \\
\text { interval }(\mathrm{cm})\end{array}$ & $\begin{array}{l}\text { Depth } \\
\text { (mcd) }\end{array}$ & $\begin{array}{c}\text { No. } \\
\text { specimens }\end{array}$ \\
\hline Catapsydrax di & ssimilis & & & & $3,14-16$ & 494.35 & 40 \\
\hline $1,14-16$ & 491.35 & 18 & 0.49 & 0.99 & $3,30-32$ & 494.51 & 16 \\
\hline $1,24-26$ & 491.45 & 10 & 0.33 & 0.98 & $3,44-46$ & 494.65 & 39 \\
\hline $1,34-36$ & 491.55 & 12 & 0.40 & 1.14 & $5,04-06$ & 497.25 & 82 \\
\hline $1,44-46$ & 491.65 & 14 & 0.36 & 1.26 & $5,14-16$ & 497.35 & 42 \\
\hline $1,54-56$ & 491.75 & 15 & 0.40 & 1.26 & $5,24-26$ & 497.45 & 20 \\
\hline $1,64-66$ & 491.85 & 10 & 0.19 & 1.26 & $5,34-36$ & 497.55 & 18 \\
\hline $1,74-76$ & 491.95 & 10 & 0.08 & 1.24 & $5,44-46$ & 497.65 & 13 \\
\hline $1,85-87$ & 492.06 & 17 & 0.38 & 1.31 & $5,52-54$ & 497.73 & 36 \\
\hline $1,94-96$ & 492.15 & 14 & 0.73 & 0.97 & $5,64-66$ & 497.85 & 30 \\
\hline $1,105-107$ & 492.26 & 30 & 0.80 & 1.05 & $5,74-76$ & 497.95 & 35 \\
\hline $1,114-116$ & 492.35 & 32 & 0.83 & 1.07 & $5,84-86$ & 498.05 & 30 \\
\hline $1,124-126$ & 492.45 & 26 & 0.79 & 1.18 & $5,96-98$ & 498.17 & 35 \\
\hline $1,134-136$ & 492.55 & 24 & 1.08 & 1.17 & $5,104-106$ & 498.25 & 27 \\
\hline $1,144-146$ & 492.65 & 31 & 0.60 & 1.23 & $5,114-116$ & 498.35 & 29 \\
\hline $2,4-6$ & 492.75 & 17 & 0.55 & 1.26 & $5,124-126$ & 498.45 & 15 \\
\hline $2,14-16$ & 492.85 & 13 & 0.24 & 1.37 & $5,134-136$ & 498.55 & 23 \\
\hline $2,24-26$ & 492.95 & 15 & 0.92 & 1.19 & $5,144-146$ & 498.65 & 22 \\
\hline $2,34-36$ & 493.05 & 14 & 0.55 & 1.16 & $6,4-6$ & 498.75 & 20 \\
\hline $2,44-46$ & 493.15 & 16 & 0.71 & 1.09 & $6,14-16$ & 498.85 & 12 \\
\hline $2,64-66$ & 493.35 & 15 & 0.56 & 0.93 & $6,22-24$ & 498.93 & 18 \\
\hline $2,74-76$ & 493.45 & 14 & 0.55 & 0.94 & $6,34-36$ & 499.05 & 10 \\
\hline $2,84-86$ & 493.55 & 12 & 0.31 & 0.88 & $6,44-46$ & 499.15 & 23 \\
\hline $2,94-96$ & 493.65 & 13 & 0.18 & 1.16 & $6,54-56$ & 499.25 & 23 \\
\hline $2,104-106$ & 493.75 & 10 & 0.4 & 1.11 & $6,64-66$ & 499.35 & 16 \\
\hline $2,114-116$ & 493.85 & 11 & -0.42 & 1.2 & $6,74-76$ & 499.45 & 40 \\
\hline $2,124-126$ & 493.95 & 6 & 0.43 & 1.39 & Globoquadrino & venezuel & \\
\hline $2,134-136$ & 494.05 & 14 & 0.36 & 1.27 & Globoquadrine & venezuel & ana \\
\hline $2,146-148$ & 494.17 & 13 & 0.64 & 1.21 & $1,14-16$ & 491.35 & 20 \\
\hline $3,4-6$ & 494.25 & 12 & 0.44 & 1.26 & $1,24-26$ & 491.45 & 24 \\
\hline $3,14-16$ & 494.35 & 14 & 0.68 & 1.28 & $1,34-36$ & 491.55 & 23 \\
\hline $3,24-26$ & 494.45 & 24 & 0.75 & 1.27 & $1,44-46$ & 491.65 & 15 \\
\hline $3,30-32$ & 494.51 & 9 & 1.15 & 1.28 & $1,54-56$ & 491.75 & 16 \\
\hline $3,44-46$ & 494.65 & 16 & 0.6 & 1.35 & $1,64-66$ & 491.85 & 18 \\
\hline $5,4-6$ & 497.25 & 16 & 0.76 & 1.27 & $1,74-76$ & 491.95 & 13 \\
\hline $5,14-16$ & 497.35 & 13 & 0.76 & 1.49 & $1,85-87$ & 492.06 & 12 \\
\hline $5,24-26$ & 497.45 & 17 & 0.73 & 1.15 & $1,94-96$ & 492.15 & 13 \\
\hline $5,34-36$ & 497.55 & 20 & 1.25 & 1.08 & $1,105-107$ & 492.26 & 12 \\
\hline $5,44-46$ & 497.65 & 14 & 0.83 & 1.35 & $1,114-116$ & 492.35 & 12 \\
\hline $5,52-54$ & 497.73 & 16 & 0.72 & 1.58 & $1,124-126$ & 492.45 & 15 \\
\hline $5,64-66$ & 497.85 & 12 & 0.45 & 1.62 & $1,134-136$ & 492.55 & 20 \\
\hline $5,74-76$ & 497.95 & 13 & 0.59 & 1.61 & $1,144-146$ & 492.65 & 16 \\
\hline $5,84-86$ & 498.05 & 12 & 0.62 & 1.29 & $2,4-6$ & 492.75 & 22 \\
\hline $5,96-98$ & 498.17 & 13 & 0.75 & 1.53 & $2,14-16$ & 492.85 & 20 \\
\hline $5,104-106$ & 498.25 & 20 & 0.79 & 1.48 & $2,24-26$ & 492.95 & 12 \\
\hline $5,114-116$ & 498.35 & 12 & 0.20 & 1.55 & $2,34-36$ & 493.05 & 12 \\
\hline $5,124-126$ & 498.45 & 13 & 0.96 & 1.29 & $2,44-46$ & 493.15 & 20 \\
\hline $5,134-136$ & 498.55 & 15 & 0.81 & 1.26 & $2,54-56$ & 493.25 & 16 \\
\hline $5,144-146$ & 498.65 & 13 & 0.58 & 1.24 & $2,64-66$ & 493.35 & 22 \\
\hline $6,4-6$ & 498.75 & 14 & 0.78 & 1.21 & $2,74-76$ & 493.45 & 17 \\
\hline $6,14-16$ & 498.85 & 14 & 0.73 & 1.18 & $2,84-86$ & 493.55 & 9 \\
\hline $6,22-24$ & 498.93 & 8 & 1.05 & 1.27 & $2,104-106$ & 493.75 & 17 \\
\hline $6,34-36$ & 499.05 & 6 & 1.10 & 1.44 & $2,114-116$ & 493.85 & 13 \\
\hline $6,44-46$ & 499.15 & 9 & 1.13 & 1.24 & $2,124-126$ & 493.95 & 16 \\
\hline $6,54-56$ & 499.25 & 12 & 0.53 & 1.42 & $2,134-136$ & 494.05 & 24 \\
\hline $6,64-66$ & 499.35 & 13 & 0.74 & 1.30 & $2,146-148$ & 494.17 & 13 \\
\hline & 499.45 & 10 & 033 & 1.41 & $3,4-6$ & 494.25 & 10 \\
\hline $0,14-10$ & 499.43 & 10 & 0.33 & 1.41 & $3,14-16$ & 494.35 & 24 \\
\hline Globigerina pr & aebulloide & & & & $3,24-26$ & 494.45 & 19 \\
\hline $1,14-16$ & 491.35 & 22 & -1.75 & 2.23 & $3,30-32$ & 494.51 & 14 \\
\hline $1,24-26$ & 491.45 & 20 & -1.72 & 1.94 & $3,44-46$ & 494.65 & 27 \\
\hline $1,34-36$ & 491.55 & 22 & -1.65 & 1.86 & $5,4-6$ & 497.25 & 23 \\
\hline $1,44-46$ & 491.65 & 19 & -1.76 & 1.97 & $5,14-16$ & 497.35 & 25 \\
\hline $1,54-56$ & 491.75 & 36 & -1.61 & 2.19 & $5,24-26$ & 497.45 & 21 \\
\hline $1,64-66$ & 491.85 & 43 & -1.59 & 1.85 & $5,34-36$ & 497.55 & 20 \\
\hline $1,74-76$ & 491.95 & 49 & -1.69 & 1.95 & $5,44-46$ & 497.65 & 25 \\
\hline $1,85-87$ & 492.06 & 17 & -1.48 & 1.87 & $5,52-54$ & 497.73 & 21 \\
\hline $1,94-96$ & 492.15 & 24 & -1.57 & 2.25 & $5,64-66$ & 497.85 & 20 \\
\hline $1,105-107$ & 492.26 & 34 & -1.61 & 1.95 & $5,74-76$ & 497.95 & 18 \\
\hline $1,114-116$ & 492.35 & 32 & -1.70 & 1.83 & $5,84-86$ & 498.05 & 18 \\
\hline $1,124-126$ & 492.45 & 30 & -1.80 & 1.81 & $5,96-98$ & 498.17 & 54 \\
\hline $1,134-136$ & 492.55 & 34 & -1.71 & 1.95 & $5,104-106$ & 498.25 & 22 \\
\hline $1,144-146$ & 492.65 & 18 & -1.64 & 1.97 & $5,114-116$ & 498.35 & 17 \\
\hline $2,4-6$ & 492.75 & 46 & -1.68 & 2.11 & $5,124-126$ & 498.45 & 17 \\
\hline $2,14-16$ & 492.85 & 41 & -1.63 & 2.13 & $5,134-136$ & 498.55 & 20 \\
\hline $2,24-26$ & 492.95 & 24 & -1.63 & 1.95 & $5,144-146$ & 498.65 & 17 \\
\hline $2,34-36$ & 493.05 & 27 & -1.62 & 1.86 & $6,4-6$ & 498.75 & 19 \\
\hline $2,44-46$ & 493.15 & 39 & -1.64 & 1.97 & $6,14-16$ & 498.85 & 16 \\
\hline $2,54-56$ & 493.25 & 23 & -1.74 & 2.02 & $6,22-24$ & 498.93 & 10 \\
\hline $2,64-66$ & 493.35 & 25 & -1.84 & 1.88 & $6,34-36$ & 499.05 & 21 \\
\hline $2,74-76$ & 493.45 & 31 & -1.9 & 1.87 & $6,44-46$ & 499.15 & 20 \\
\hline $2,84-86$ & 493.55 & 11 & -1.21 & 1.46 & $6,54-56$ & 499.25 & 21 \\
\hline $2,94-96$ & 493.65 & 13 & -1.44 & 2.17 & $6,64-66$ & 499.35 & 17 \\
\hline $2,104-106$ & 493.75 & 39 & -1.83 & 1.99 & $6,74-76$ & 499.45 & 16 \\
\hline $2,114-116$ & 493.85 & 30 & -1.68 & 1.86 & & ia maver & \\
\hline $2,124-126$ & 493.95 & 31 & -1.68 & 2.1 & Paragloborota & ia mayer & \\
\hline $2,134-136$ & 494.05 & 56 & -1.56 & 2.25 & $1,14-16$ & 491.35 & 29 \\
\hline $2,146-148$ & 494.17 & 50 & -1.53 & 2.25 & $1,24-26$ & 491.45 & 33 \\
\hline $3,4-6$ & 494.25 & 41 & $\begin{array}{l}-1.53 \\
-1.57\end{array}$ & 2.05 & $1,34-36$ & 491.55 & 35 \\
\hline $3,4-0$ & & 41 & $-1.5 /$ & 2.00 & $1,44-46$ & 491.65 & 35 \\
\hline
\end{tabular}


Table 2 (continued).

\begin{tabular}{ccccc}
\hline $\begin{array}{c}\text { Section, } \\
\text { interval (cm) }\end{array}$ & $\begin{array}{c}\text { Depth } \\
\text { (mcd) }\end{array}$ & $\begin{array}{c}\text { No. } \\
\text { specimens }\end{array}$ & $\begin{array}{l}\delta^{18} \mathrm{O} \\
(\%)\end{array}$ & $\begin{array}{l}\delta^{13} \mathrm{C} \\
(\%)\end{array}$ \\
\hline $1,54-56$ & 491.75 & 41 & -1.26 & 1.76 \\
$1,64-66$ & 491.85 & 52 & -1.32 & 1.51 \\
$1,74-76$ & 491.95 & 37 & -1.18 & 1.50 \\
$1,85-87$ & 492.06 & 51 & -1.07 & 1.49 \\
$1,94-96$ & 492.15 & 43 & -1.20 & 1.48 \\
$1,105-107$ & 492.26 & 63 & -1.08 & 1.32 \\
$1,114-116$ & 492.35 & 71 & -1.40 & 1.30 \\
$1,124-126$ & 492.45 & 85 & -1.29 & 1.29 \\
$1,134-136$ & 492.55 & 89 & -1.19 & 1.39 \\
$1,144-146$ & 492.65 & 48 & -1.12 & 1.49 \\
$2,4-6$ & 492.75 & 73 & -1.20 & 1.56 \\
$2,14-16$ & 492.85 & 31 & -1.34 & 1.56 \\
$2,24-26$ & 492.95 & 47 & -1.15 & 1.55 \\
$2,34-36$ & 493.05 & 62 & -1.40 & 1.39 \\
$2,44-46$ & 493.15 & 21 & -1.63 & 1.45 \\
$2,54-56$ & 493.25 & 41 & -1.52 & 1.30 \\
$2,64-66$ & 493.35 & 51 & -1.58 & 1.19 \\
$2,7-76$ & 493.45 & 59 & -1.49 & 1.33 \\
$2,84-86$ & 493.55 & 74 & -1.52 & 1.2 \\
$2,94-96$ & 493.65 & 61 & -1.36 & 1.39 \\
$2,104-106$ & 493.75 & 41 & -1.3 & 1.39 \\
$2,14-116$ & 493.85 & 35 & -1.44 & 1.54 \\
$2,124-126$ & 493.95 & 44 & -1.45 & 1.62 \\
$2,134-136$ & 494.05 & 52 & -1.32 & 1.54 \\
$2,14-148$ & 494.17 & 49 & -1.36 & 1.5 \\
$3,4-6$ & 494.25 & 54 & -1.2 & 1.45 \\
$3,14-16$ & 494.35 & 62 & -1.17 & 1.49 \\
$3,24-26$ & 494.45 & 70 & -1.21 & 1.46 \\
$3,30-32$ & 494.51 & 82 & -1.27 & 1.5 \\
$3,4-46$ & 494.65 & 62 & -1.21 & 1.64 \\
$5,4-6$ & 497.25 & 31 & -0.96 & 1.66 \\
$5,14-16$ & 497.35 & 30 & -1.42 & 1.50 \\
$5,24-26$ & 497.45 & 35 & -1.08 & 1.51 \\
$5,34-36$ & 497.55 & 35 & -1.05 & 1.45 \\
$5,44-46$ & 497.65 & 39 & -1.04 & 1.75 \\
$5,52-54$ & 497.73 & 41 & -0.94 & 1.83 \\
$5,64-66$ & 497.85 & 40 & -0.90 & 1.64 \\
$5,74-76$ & 497.95 & 42 & -0.86 & 1.70 \\
$5,84-86$ & 498.05 & 46 & -0.85 & 1.59 \\
$5,96-98$ & 498.17 & 44 & -0.99 & 1.57 \\
$5,104-106$ & 498.25 & 55 & -1.17 & 1.75 \\
$5,14-116$ & 498.35 & 49 & -0.92 & 1.74 \\
$5,124-126$ & 498.45 & 45 & -1.13 & 1.66 \\
$5,134-136$ & 498.55 & 45 & -1.09 & 1.34 \\
$5,14-146$ & 498.65 & 32 & -1.15 & 1.45 \\
$6,4-6$ & 498.75 & 43 & -1.03 & 1.51 \\
$6,14-16$ & 498.85 & 49 & -1.13 & 1.36 \\
$6,22-24$ & 498.93 & 46 & -1.31 & 1.35 \\
$6,34-36$ & 499.05 & 42 & -1.26 & 1.62 \\
$6,44-46$ & 499.15 & 50 & -1.38 & 1.52 \\
$6,54-56$ & 499.25 & 39 & -1.59 & 1.62 \\
$6,64-66$ & 499.35 & 37 & -0.99 & 1.62 \\
$6,74-76$ & 499.45 & 33 & -1.24 & 1.31 \\
Paragloborotalia pseudokugleri/kugleri & & \\
$1,14-16$ & 491.35 & 71 & -1.55 & 1.91 \\
$1,24-26$ & 491.45 & 42 & -1.51 & 2.06 \\
& & & &
\end{tabular}

$\delta^{18} \mathrm{O}$ minima in the deeper dwelling planktonic foraminifers (further work is required to investigate this), it is not paralleled in the records of shallow-dwelling planktonic foraminifers in this stratigraphic interval. Given convincing evidence elsewhere for glaciation in the late Oligocene and early Miocene, we regard the lack of cyclicity in $\delta^{18} \mathrm{O}$ in shallow-dwelling planktonic foraminifers as anomalous. One possibility is that the short interval studied here was relatively ice-free compared to times shortly before and afterwards. However, it should be stressed that a lack of cyclicity in ice volume does not necessarily imply an absence of ice.

If major ice volume and temperature changes did not occur during the time that the lithologic cycles studied here were deposited, it still remains to explain why the sediment is cyclic. Three factors could produce variations in clay/carbonate ratio: 1) changes in the rate of carbonate supply, 2) changes in the rate of terrigenous supply, and 3) changes in the degree of carbonate dissolution. Weedon and Shackleton (this volume) discuss the causes of sediment cyclicity at several levels on the Ceara Rise, including the interval studied here, in the light of major and trace element analyses. They observed significantly higher ratios of barium to aluminum and phosphorus to aluminum than those observed in the Miocene and recent, which they interpret as indicating enhanced biological productivity. They also observed

\begin{tabular}{lrrrl}
\hline $\begin{array}{c}\text { Section, } \\
\text { interval (cm) }\end{array}$ & $\begin{array}{c}\text { Depth } \\
\text { (mcd) }\end{array}$ & $\begin{array}{c}\text { No. } \\
\text { specimens }\end{array}$ & $\begin{array}{l}\delta^{18} \mathrm{O} \\
(\%)\end{array}$ & $\begin{array}{l}\delta^{13} \mathrm{C} \\
(\% \circ)\end{array}$ \\
\hline $1,34-36$ & 491.55 & 48 & -1.50 & 2.18 \\
$1,44-46$ & 491.65 & 71 & -1.39 & 2.09 \\
$1,54-56$ & 491.75 & 49 & -1.61 & 2.16 \\
$1,64-66$ & 491.85 & 58 & -1.54 & 2.20 \\
$1,74-76$ & 491.95 & 62 & -1.60 & 2.21 \\
$1,85-87$ & 492.06 & 46 & -1.26 & 2.04 \\
$1,94-96$ & 492.15 & 94 & -1.35 & 2.01 \\
$1,105-107$ & 492.26 & 101 & -1.57 & 1.70 \\
$1,114-116$ & 492.35 & 113 & -1.64 & 1.98 \\
$1,124-126$ & 492.45 & 83 & -1.33 & 1.81 \\
$1,134-136$ & 492.55 & 95 & -1.43 & 1.90 \\
$1,144-146$ & 492.65 & 86 & -1.46 & 2.09 \\
$2,4-6$ & 492.75 & 70 & -1.54 & 2.36 \\
$2,14-16$ & 492.85 & 74 & -1.40 & 2.07 \\
$2,24-26$ & 492.95 & 71 & -1.38 & 1.98 \\
$2,34-36$ & 493.05 & 78 & -1.50 & 1.88 \\
$2,44-46$ & 493.15 & 67 & -1.29 & 1.68 \\
$2,54-56$ & 493.25 & 45 & -1.43 & 1.68 \\
$2,64-66$ & 493.35 & 45 & -1.98 & 1.78 \\
$2,74-76$ & 493.45 & 67 & -1.99 & 2.01 \\
$2,84-86$ & 493.55 & 81 & -1.98 & 2 \\
$2,94-96$ & 493.65 & 63 & -1.29 & 1.68 \\
$2,104-106$ & 493.75 & 82 & -1.92 & 2.17 \\
$2,114-116$ & 493.85 & 94 & -1.67 & 2.33 \\
$2,124-126$ & 493.95 & 44 & -1.65 & 2.2 \\
$2,134-136$ & 494.05 & 61 & -1.57 & 2.39 \\
$2,146-148$ & 494.17 & 95 & -1.67 & 2.42 \\
$3,04-06$ & 494.25 & 87 & -1.66 & 2.25 \\
$3,14-16$ & 494.35 & 57 & -1.42 & 2.21 \\
$3,24-26$ & 494.45 & 91 & -1.63 & 2.34 \\
$3,30-32$ & 494.51 & 72 & -1.75 & 2.17 \\
$3,44-46$ & 494.65 & 90 & -1.38 & 2.23 \\
$5,4-6$ & 497.25 & 51 & -1.26 & 2.02 \\
$5,14-16$ & 497.35 & 78 & -1.35 & 1.93 \\
$5,24-26$ & 497.45 & 77 & -1.48 & 1.86 \\
$5,34-36$ & 497.55 & 82 & -1.69 & 1.91 \\
$5,44-46$ & 497.65 & 94 & -1.60 & 2.23 \\
$5,52-54$ & 497.73 & 92 & -1.66 & 2.45 \\
$5,64-66$ & 497.85 & 97 & -1.61 & 2.21 \\
$5,74-76$ & 497.95 & 101 & -1.64 & 2.33 \\
$5,84-86$ & 498.05 & 111 & -1.56 & 2.15 \\
$5,96-98$ & 498.17 & 127 & -1.29 & 2.00 \\
$5,104-106$ & 498.25 & 117 & -1.52 & 2.02 \\
$5,114-116$ & 498.35 & 94 & -1.45 & 1.94 \\
$5,124-126$ & 498.45 & 109 & -1.59 & 2.09 \\
$5,134-136$ & 498.55 & 114 & -1.60 & 2.02 \\
$5,144-146$ & 498.65 & 78 & -1.43 & 1.93 \\
$6,4-6$ & 498.75 & 66 & -1.61 & 2.01 \\
$6,14-16$ & 498.85 & 99 & -1.58 & 1.87 \\
$6,22-24$ & 498.93 & 107 & -1.70 & 1.67 \\
$6,34-36$ & 499.05 & 101 & -1.75 & 1.92 \\
$6,74-76$ & 499.15 & 104 & -1.70 & 1.77 \\
& 499.25 & 110 & -1.69 & 2.01 \\
& 499.45 & 106 & -1.54 & 1.86 \\
& & & & \\
\hline
\end{tabular}

cyclicity in $\mathrm{Ba} / \mathrm{Al}$ which occurs in phase with the light reflectance and estimated $\% \mathrm{CaCO}_{3}$. They interpret this cyclicity in terms of varying productivity in the water column, although variable terrigenous flux and/or carbonate dissolution might also cause cyclic $\mathrm{Ba} / \mathrm{Al}$ ratios.

If large changes in biological productivity occurred during the cycles, the surface- to deep-dwelling planktonic foraminifer $\delta^{13} \mathrm{C}$ gradient would be expected to vary in phase with reflectance. This is because the "biological pump" would be stronger during times of high productivity, increasing both the $\delta^{13} \mathrm{C}$ gradient in the water column and the carbonate flux. The following equation combines data from both shallow-dwelling species to estimate the planktonic carbon isotope gradient:

$$
\begin{aligned}
& \Delta \delta^{13} C_{\text {planktonic }}=\left[\left(\delta^{13} C_{P . \text { pseudokugleri }}-\delta^{13} C_{C . \text { dissimilis }}\right)\right. \\
& \left.+\left(\delta^{13} C_{\text {G. praebulloides }}-\delta^{13} C_{C \text {. dissimilis }}\right)\right] / 2 .
\end{aligned}
$$

Values for $\Delta \delta^{13} C_{\text {planktonic }}$ are plotted against light reflectance for the whole of Core 154-926B-50X in Figure 5. It can be seen from the figure that $\Delta \delta^{13} \mathrm{C}_{\text {planktonic }}$ varies erratically between about $0.3 \%$ and $1.3 \%$ with a temporal shift to slightly higher values. However, 


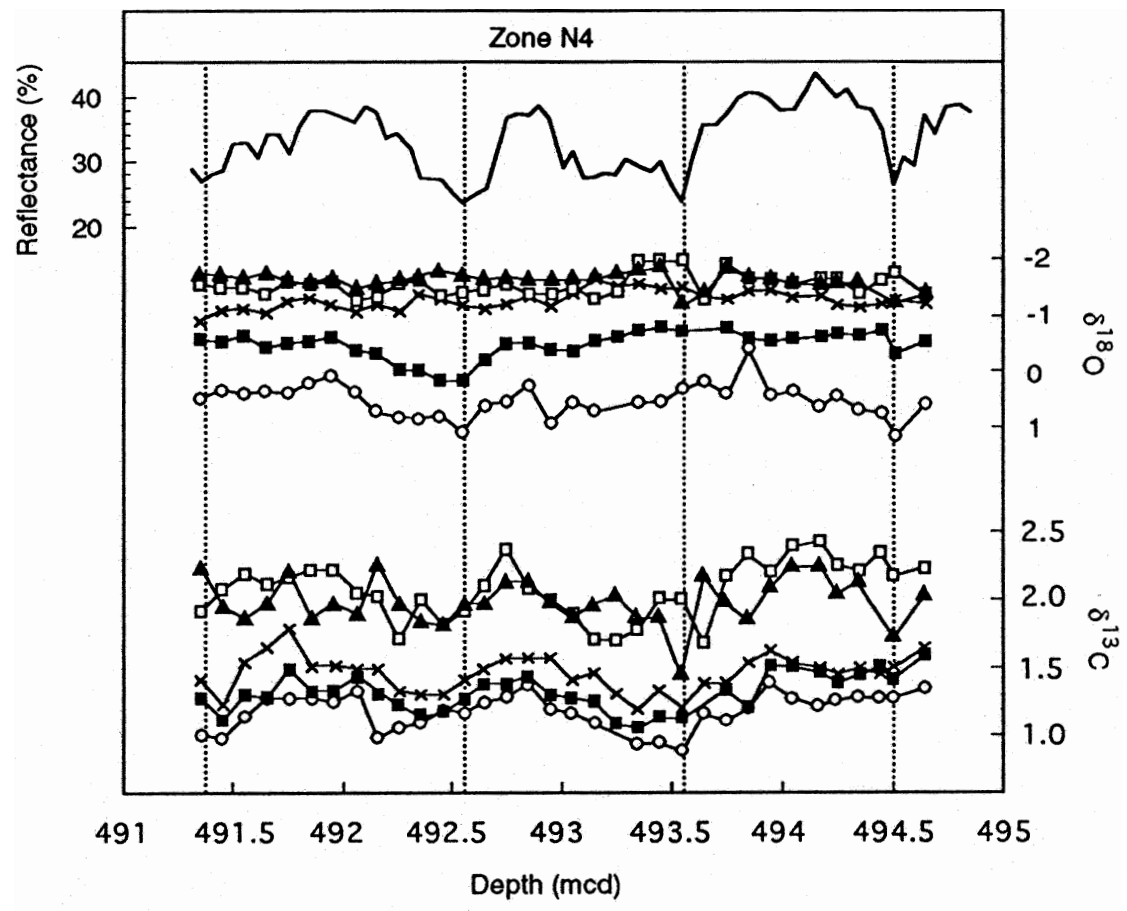

^A G. praebulloides o- P P.pseudokugleri/kugleri $\star x P$. mayeri $\rightarrow G$. venezuelana o- $C$. dissimilis

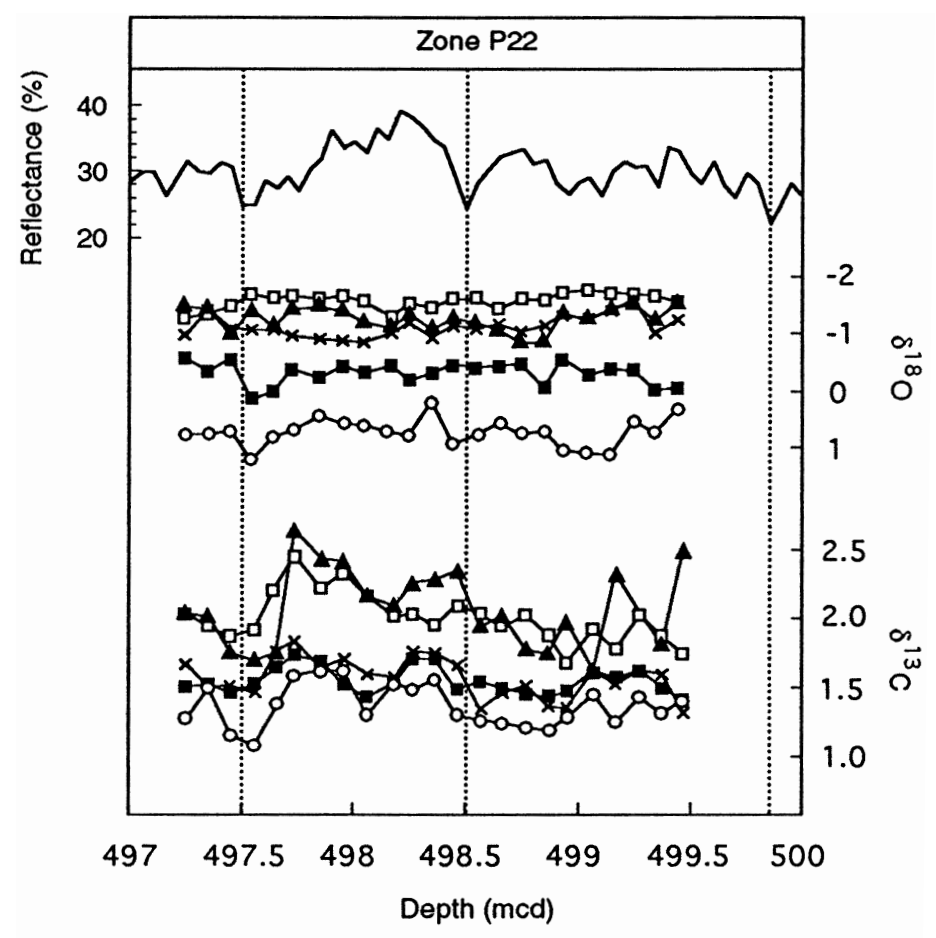

$\triangle$ G. praebulloides a- P.pseudokugleri

$\star x$ P. mayeri $\because G$. venezuelana $\circ \circ C$. dissimilis
Figure 3. Stable isotope stratigraphies for five species of planktonic foraminifer and light reflectance curve for the higher sampling interval in Core 154-926B-50X Note that the depth scale is in mcd, which is significantly greater than the real depth of approximately 460 464 mbsf.
Figure 4. Stable isotope stratigraphies for five species of planktonic foraminifer and light reflectance curve for the lower sampling interval in Core 154-926B-50X. Note that the depth scale is in mcd, which is significantly greater than the real depth of approximately $466-469$ mbsf. 


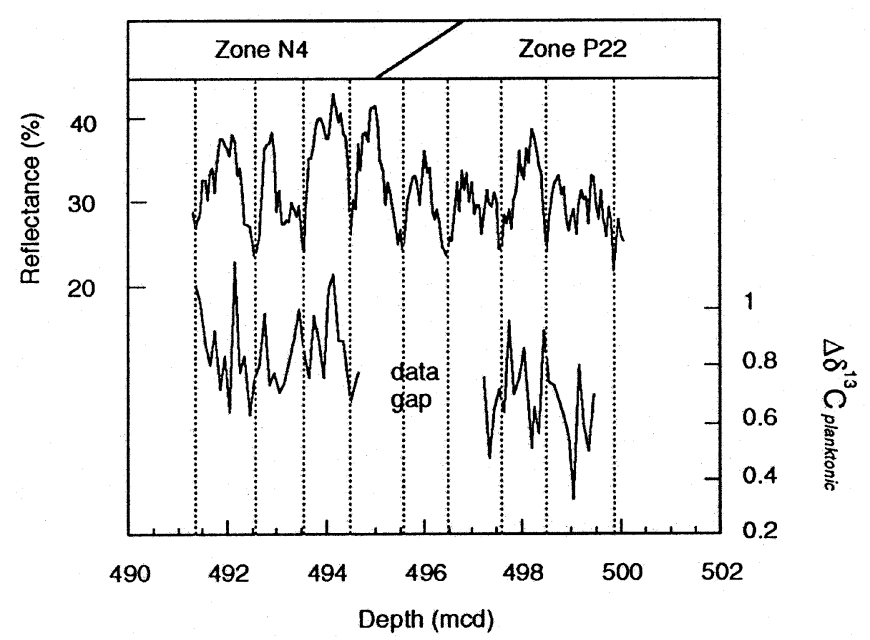

Figure 5. Light reflectance (top curve) plotted against shallow- to deepplanktonic foraminifer carbon isotope gradient (bottom curve) for the whole of Core 154-926B-50X. The boundary between Zones P22 and N4 cannot be determined more precisely without detailed morphometric analysis because it is a gradual transition.

$\Delta \delta^{13} C_{\text {planktonic }}$ does not vary systematically in each cycle as would be expected if there were marked changes in biological productivity associated with the lithologic cycles. We interpret this as indicating that if productivity changes did occur, they were not of sufficient magnitude to affect $\Delta \delta^{13} C_{\text {planktonic }}$ systematically. Other factors, such as changes in the rate of terrigenous supply and dissolution were probably involved.

A visual examination of the sediment samples reveals extensive evidence of dissolution. In particular, the dark bands contain fewer whole foraminifers, a higher concentration of fragments, and a higher proportion of individuals belonging to dissolution-resistant species than the light bands. It is therefore hypothesized that periodic influxes of cooler water enhanced dissolution on the Ceara Rise and increased the clay:carbonate ratio on the sea floor. Some of these postulated cooling events may have also affected the $\delta^{18} \mathrm{O}$ of the deeper dwelling planktonic foraminifers. If the deep water was sourced from the high latitudes, this scenario would explain why obliquity and not precession is the dominant cyclic frequency in this interval, because obliquity has a greater effect on insolation at the higher latitudes.

The carbon isotopic record is also potentially informative with respect to Oligocene/Miocene boundary climate. Variation in $\delta^{13} \mathrm{C}$ seems to be about the same wavelength of the lithologic cycles, indicating a duration of about 40,000 yr. This duration indicates that obliquity is also a likely cause for these variations, although there may also be a subtle precessional component having about half the wavelength (more data are required). The upward trend in $\Delta \delta^{13} \mathrm{C}_{\text {planktonic }}$ observed through the core (Fig. 5) may represent slowly increasing productivity at this site, but with considerable short-term variation. Because all species approximately covary in $\delta^{13} \mathrm{C}$ regardless of their depth habitat, a global signal is suggested for the Milankovitch-scale variations, rather than a local signal such as productivity changes or surface or intermediate water-mass switching. A total water-column signal could result from either changing terrestrial biomass volume or, more likely, changes in the rate of organic carbon storage. It is premature to speculate on the precise causes for such changes until more data are available.

Clearly, further work is required to investigate some of the patterns described in this paper. Longer time series are desirable so power spectra can be made from the isotopic records, from which more subtle patterns might emerge. Benthic foraminifer data from Site 926 would allow us to measure the magnitude of bottom water $\delta^{18} \mathrm{O}$ fluctuations and compare them with the planktonic records. Note also that the present study was conducted on just a small portion of the long sedimentary record of the Ceara Rise. The data underline the great potential for Leg 154 sediments in revealing new information about climate in the Oligocene and Miocene.

\section{ACKNOWLEDGMENTS}

We would like to thank two anonymous reviewers for several useful suggestions. PNP was supported by a Royal Society University Research Fellowship. NJS, PNP, and GPW were supported by NERC Grant GST/02/971.

\section{REFERENCES}

Barrera, E., Keller, G., and Savin, S.M., 1985. Evolution of the Miocene ocean in the eastern North Pacific as inferred from oxygen and carbon isotopic ratios of foraminifera. In Kennett, J.P. (Ed.), The Miocene Ocean: Palaeoceanography and Biogeography, Mem. Geol. Soc. Am., 163:83-102.

Berger, A., and Loutre, M.F., 1994. Astronomical forcing through geologic time. In de Boer, P.L., and Smith, D.G. (Eds.), Orbital Forcing and Cyclic Sequences, Spec. Publ.-Int. Assoc. Sed. Special Pub., 19:15-24.

Berggren, W.A., Kent, D.V., Swisher, C.C., and Aubry, M., 1995. A revised Cenozoic geochronology and chronostratigraphy. In Berggren, W.A., Kent, D.V., Aubry, M., and Hardenbol, J. (Eds.), Geochronology, Time Scales and Global Stratigraphic Correlation, Spec. Publ.-Soc. Econ. Paleontol. Mineral., 54:129-212.

Bijma, J., Spero, H.J., Bemis, B.E., and Lea, D.W., 1995. Effect of seawater carbonate chemistry on the carbon and oxygen isotope composition of foraminiferal calcite. 5th Int. Conf. Paleoceanog., Progr. Abstr., 31.

Boersma, A., Premoli Silva, I., and Shackleton, N.J., 1987. Atlantic Eocene planktonic foraminiferal paleohydrographic indicators and stable isotope paleoceanography. Paleoceanography, 2:287-331.

Corfield, R.M., and Cartlidge, J.E., 1991. Isotopic evidence for the depth stratification of fossil and Recent Globigerinina: a review. Hist. Biol., $5: 37-63$.

, 1993. Oxygen and carbon isotope stratigraphy of the middle Miocene, Holes 805B and 806B. In Berger, W.H., Kroenke, L.W., Mayer, L.A., et al., Proc. ODP, Sci. Results, 130: College Station, TX (Ocean Drilling Program), 307-322.

Curry, W.B., Shackleton, N.J., Richter, C., et al., 1995. Proc. ODP, Init. Repts., 154: College Station, TX (Ocean Drilling Program).

Douglas, R.G., and Savin, S.M., 1978. Oxygen isotopic evidence for the depth stratification of Tertiary and Cretaceous planktic foraminifera. Mar. Micropaeontol., 3:175-196.

Emiliani, C., 1954. Depth habitats of some species of pelagic foraminifera as indicated by oxygen isotope ratios. Am. J. Sci., 252:149-158.

Erez, J., and Honjo, S., 1981. Comparison of isotopic composition of planktonic foraminifera in plankton tows, sediment traps and sediments. Paleogeogr., Palaeoclimatol., Palaeoecol., 33:129-156.

Gasperi, J.T., and Kennett, J.P., 1992. Isotopic evidence for depth stratification and paleoecology of Miocene planktonic foraminifera: western equatorial Pacific DSDP Site 289. In Tsuchi, R., and Ingle, J.C., Jr, (Eds.), Pacific Neogene: Tokyo (Univ. of Tokyo Press), 117-147.

, 1993. Vertical thermal structure evolution of Miocene surface waters: western equatorial Pacific DSDP Site 289, Mar. Micropaleontol., 22:235-254.

Hartl, P., Tauxe, L., and Herbert, T., 1995. Earliest Oligocene increase in South Atlantic productivity as interpreted from "rock magnetics" at Deep Sea Drilling Project Site 522. Paleoceanography, 10:311-326.

Hemleben, C., Spindler, M., and Anderson, O.R., 1989. Modern Planktonic Foraminifera: New York (Springer-Verlag).

Hodell, D.A., and Vayavananda, A., 1993. Middle Miocene paleoceanography of the western equatorial Pacific (DSDP Site 289) and the evolution of Globorotalia (Fohsella). Mar. Micropal., 22:279-310.

Keller, G., 1985. Depth stratification of planktonic foraminifers in the Miocene ocean. In Kennett, J.P. (Ed.), The Miocene Ocean: Paleoceanography and Biogeography, Mem. Geol. Soc. Am., 163:177-196. 
Kroopnick, P.M., 1985. The distribution of ${ }^{13} \mathrm{C}$ of $\Sigma \mathrm{CO}_{2}$ in the world oceans. Deep-Sea Res., 32:57-84.

Mead, G.A., Tauxe, L., and LaBreque, J.L., 1986. Oligocene paleoceanography of the South Atlantic: paleoclimatic implications of sediment accumulation rates and susceptibility measurements. Paleoceanography, 1:273-284.

Norris, R.D., Corfield, R.M., and Cartlidge, J.E., 1993. Evolution of depth ecology in the planktic foraminifera lineage Globorotalia (Fohsella). Geology, 21:975-978.

Pearson, P.N., and Shackleton, N.J., 1995. Neogene multispecies planktonic foraminifer stable isotope record, Site 871, Limalok Guyot. In Haggerty, J.A., Premoli Silva, I., Rack, F., and McNutt, M.K. (Eds.), Proc. ODP, Sci. Results, 144: College Station, TX (Ocean Drilling Program), 401410.

Pearson, P.N., Shackleton, N.J., and Hall, M.A., 1993. Stable isotope paleoecology of middle Eocene planktonic foraminifera and multi-species isotope stratigraphy, DSDP Site 523, South Atlantic. J. Foraminiferal Res., 23:123-140.

Poore, R.Z., and Matthews, R.K., 1984. Oxygen isotope ranking of late Eocene and Oligocene planktonic foraminifers: implications for Oligocene sea-surface temperatures and global ice volume. Mar. Micropaleontol., 9:111-134.
Shipboard Scientific Party, 1995. Site 926. In Curry, W.B., Shackleton, N.J., Richter, C., et al., Proc. ODP, Init. Repts., 154: College Station, TX (Ocean Drilling Program), 153-232.

Spero, H.J., 1992. Do planktic foraminifera accurately record shifts in the carbon isotopic composition of seawater $\mathrm{\Sigma CO}_{2}$ ? Mar. Micropaleontol., 19:275-285.

Spero, H.J., and Williams, D.F., 1988. Extracting environmental information from planktonic foraminifer $\delta^{13} \mathrm{C}$ data. Nature, 355:717-719.

1989. Opening the carbon isotope "vital effect" black box 1. Seasonal temperatures in the euphotic zone. Paleoceanography, 4:593-601.

Steininger, F.F., 1994. Proposal for the global stratotype section and point (GSSP) for the base of the Neogene (the Paleogene/Neogene boundary), Working Group on the Paleogene/Neogene boundary, Int. Comm. Stratig., Subcomm. Neogene Stratig.: (Vienna), 1-41.

Van Echelpoel, E., and Weedon, G.P., 1990. Milankovitch cyclicity and the Boom Clay Formation: an Oligocene siliciclastic shelf sequence in Belgium. Geol. Mag., 127:599-604.

Date of initial receipt: 5 December 1995

Date of acceptance: 17 August 1996

Ms 154SR-118 